\title{
Adult literacy classes in Timor-Leste and diverse language values and practices across the regions: implications for language policy-making
}

\section{Danielle Boon ${ }^{1} \cdot$ Edegar da Conceição Savio $^{1} \cdot$ Sjaak Kroon $^{1}$ (D) · Jeanne Kurvers ${ }^{1}$}

Received: 29 February 2020 / Accepted: 4 September 2020 / Published online: 29 September 2020

(c) The Author(s) 2020

\begin{abstract}
This article draws on two studies of language diversity and adult literacy education in Timor-Leste that were conducted in different regions of the country between 2009 and 2013. Its central focus is on the day-to-day language practices and language values of local participants and the way in which these practices and values relate to national language policies. We first outline the views of language and of language policy-making that underpin our article. We then provide a brief overview of language-in-education policy-making in Timor-Leste with respect to provision for adult literacy. After that, we describe the design and conduct of the two studies and we present selected findings, drawing on both quantitative and qualitative data sources. The quantitative data were generated by means of questionnaire-based interviews and the research participants' own accounts of their language repertoires, practices and values. The qualitative data were gathered via: (1) observation of adult literacy classes; (2) analysis of photographs of signage in local linguistic landscapes. We conclude with a discussion of the implications of our findings for language-ineducation policy development in the area of adult literacy provision in countries in the global south, such as Timor-Leste. Here we plead for a greater involvement of teachers and learners as actors, not mere bystanders, who can bring new voices into policy-making processes and into research into these processes.
\end{abstract}

Keywords Language policy processes · Adult literacy $\cdot$ Linguistic landscapes · Multilingualism $\cdot$ Language resources and repertoires $\cdot$ Language values and attitudes $\cdot$ Language practices $\cdot$ Timor-Leste

Sjaak Kroon

s.kroon@tilburguniversity.edu

1 Department of Culture Studies, Tilburg School of Humanities and Digital Sciences, Tilburg University, Tilburg, The Netherlands 


\section{Introduction}

This article is about national language policies and local language values and practices in multilingual Timor-Leste. It draws on two studies which focused on language values, language practices and adult literacy education, in different regions of the country. The research was carried out between 2009 and 2013, as part of a larger research project on adult literacy (De Araújo e Corte-Real and Kroon 2012). ${ }^{1}$ The main aim was to investigate the language practices and attitudes of adults in different regions of Timor-Leste, including literacy teachers and adult learners, and to build a picture of how their practices and attitudes related to national language policies. In section two, we set out our approach to language and to language policy, along with the particular research lenses that we were employing in interpreting and analyzing the different types of data that were generated by the two studies.

In section three, we chart changes that have taken place over time in TimorLeste's language-in-education policies. Section four deals with the methodology of the two studies and describes how the empirical work was designed and carried out in different regions. In section five, we present the research findings, taking account of the language resources and communicative repertoires of the research participants in different regions and their language practices and attitudes. We also present an account of language use in signage across local linguistic landscapes. Section six then summarizes the findings and discusses the way in which our findings relate to national language-in-education policies in Timor-Leste.

\section{Researching contexts for adult literacy and language-in-education policy: taking account of local social actors and sociolinguistic realities}

Policy decisions, such as those relating to adult literacy education in Timor-Leste, are generally defined within the framework of a country's overall language-in-education policy, which is part of a more general national policy framework. Policymaking processes of this kind are characterised by Johnson (2013: 10) as 'top-down' processes, that is, they begin at the 'macro' level, they are "overtly expressed in written or spoken policy texts" and they are enshrined in law (i.e. they are de jure).

For several decades, the main focus of research on language policy and planning was on such 'top-down' processes, and on macro-level policy developments (i.e. on a national level). This research was largely based in new nations of the global south, in Africa and Asia, that were emerging from colonial rule in the period following World War II. As we see from various handbooks on language policy (Cooper 1989; Kaplan and Baldauf 1997; Marten 2016), researchers in the

\footnotetext{
1 This research was based at Tilburg University, The Netherlands, and it was funded by NWO-WOTRO Science for Global Development, Netherlands Organisation for Scientific Research (Project No. WO1.65.315.00). The title of the wider research project was: Becoming a nation of readers in TimorLeste: Language policy and adult literacy development in a multilingual context.
} 
field at the time were primarily concerned with status and corpus planning activities and with the elite social actors involved in these activities.

Along with the study of the political processes involved in status planning, the study of corpus development involved the tracing of the processes at work in the codification of particular local languages and the development of orthographic conventions. As we now know, the discursive processes involved in the construction of local language varieties as fixed and bounded codes focused on language forms rather than on speakers, and on their actual communicative practices (Makoni and Pennycook 2007; Makoni and Mashiri 2007).

As attention turned to the role of different sectors of education-primary, secondary and adult education-in policy implementation processes, "acquisition planning" was added to the range of policy-related activities (Cooper 1989). And, as Heller (2018) has pointed out, researchers and research foundations from the countries of the global north (notably the United States) were closely involved in supporting research into all three language planning activities: status, corpus and acquisition planning.

In this period of sociolinguistic research, from the early 1960s to the late 1980s, there was a significant divide between macro-level and micro-level research. As Martin-Jones and Da Costa Cabral (2018: 72) have put it:

On the one hand, there was macro-level research, that was explicitly related to language policy and planning and, on the other hand, there was a distinct tradition of micro-level research of an interpretive and ethnographic nature that was being carried out in schools and classrooms where language policies were being translated into day to day educational practices.

Despite the obvious relevance of this micro-level research to macro-level research on language policy, there was practically no scholarly interaction between researchers working at different levels.

With the advent of critical approaches to language policy, new ways of bridging the macro-micro divide were conceptualised. For example, in the 1990s, the incorporation of poststructuralist perspectives into research on the discursive and interactional practices of teachers and learners in multilingual classrooms (e.g. Canagarajah 1993; Arthur 1996; Lin 1996; Heller 1999) made it possible to provide more explanatory accounts of these practices, to show why they were the way they were, taking account of historical, structural and ideological processes. A substantial proportion of this research was carried out in global south contexts, similar to that in Timor-Leste, or in minority language settings.

These developments coincided with the forging of a critical ethnographic approach to language policy. Ricento and Hornberger (1996: 408) put forward the case for paying more attention to "agents, levels and processes" in language policy-making and to policy-related processes at work on different levels (or layers) of social and institutional life. A decade later, the field of ethnography of language policy had come into its own, with key contributions to theory-building and to empirical work from Hornberger (2006), Hornberger and Johnson (2007), McCarty (2011) and Johnson (2013). Hornberger and Johnson (2007) reiterated 
the need for a "multi-layered" approach to policy-making. They also argued that analyses of language policy documents and historical accounts of the ideological processes underpinning policy developments needed to be combined with ethnography. As they put it (2007: 528):

An ethnography of language policy can include textual and historical analyses of policy texts but must be based in an ethnographic understanding of some local context. The texts are nothing without the human agents who act as interpretive conduits between the language policy levels.

In a later paper on language-in-education policy, Johnson (2009: 142) unpacked as follows, the ways in which policy-making has traditionally been conceptualised:

Traditional divisions between policy formation and implementation implicitly ratify a top-down perspective by characterising those in power as legislating directives that are implemented by practitioners. Instead, 'policy' is a dynamic process that stretches across time, and implementation or 'appropriation' is not just what happens after policy is made - it is a link in a chain of policy process in which all actors potentially have input.

Instead of the traditional two-way distinction between policy and implementation, Johnson (2009) argued that policy-making needs to be conceptualised as three broad processes: Policy creation, interpretation and appropriation. The inclusion of the role of interpretation is important, since social actors construe policies in different ways and have differing degrees of understanding of them. The term 'appropriation' covers a range of possibilities, not just compliance or acceptance but also adaptation and recasting. In later work by E.J. Johnson (2012), a fourth process was added to the three conceptualised by Johnson (2009). This was referred to as 'instantiation'. This term refers to the ways in which language policies are actually appropriated 'on the ground' (e.g. in local classrooms), through specific types of language and literacy practices.

Research and theory-building related to language policy processes is still evolving, in increasingly diverse and complex ways, but there is general agreement among researchers, that to fully capture how policy-making unfolds, we need to take account of and illuminate policy processes on multiple levels. However, within the time span of most research projects, working across several different levels is not always possible. As Hult (2010) has observed, this is a "perennial challenge" for the field of language policy. Most researchers focus on one or two levels, depending on constraints of time and access, and on the processes at work on those levels. This was the case with the research in Timor-Leste that we present here.

Part of the research focused on the process of instantiation of language-in-education policy in the context of adult literacy classes, in different regions of TimorLeste. This was ethnographically-informed research that involved observation of adult literacy classes, and interviews with teachers and groups of adult learners. This research provided insights into the ways in which local adult literacy teachers navigated the national language-in-education policy for adult education, in the 
daily rounds of classroom life. The interviews with teachers also enabled us to glean their perspectives on the language practices in their classes.

The other part of the research was devoted to: (1) researching the language practices and the values associated with different languages by adults in different regions where adult literacy provision had been developed; and (2) to building an account of the characteristics of the local linguistic landscapes and the multilingual signage in each region. Both types of research can contribute to wider debate about languagein-education policy-making, albeit in different ways. In the final section of this article, we will consider the implications of the findings of both types of research for language-in-education policy-making in adult education in Timor-Leste.

As we implied earlier in this section, our account in this article, is guided by a view of language as resources for communication. We see speakers as drawing on different linguistic resources, vernacular forms, and styles, as well as different genres and registers, across different social domains, in speech and in writing (Blommaert and Kroon 2015). The language practices observable across domains are not idiosyncratic, they follow specific local norms and have indexical effects (Silverstein 2003).

To fully understand the contexts and challenges for national language policymaking, detailed accounts of local language practices and values are needed, in different regions. In the section that follows, to set out the context for our research in Timor-Leste, we begin by sketching out the broad contours of national languagepolicy making with regard to different sectors of education, since independence in 2002.

\section{Language-in-education policy in Timor-Leste}

The language-in-education policy of Timor-Leste has, as its foundations, the national language policy which is enshrined in sections 13 and 159 of the 2002 Constitution: Portuguese and Tetum are the country's two official languages, Indonesian and English are accepted as working languages, and the other languages of TimorLeste (referred to as 'national languages' in the Constitution) are to be valued and developed by the state (RDTL 2002a). In 2004, the country's National Institute of Linguistics (INL) was appointed 'scientific custodian of Official Tetum' by means of a Government decree, and was also given the task of developing scientific activities necessary for the preservation and protection of the other national languages, devising orthographical standards for each of them (RDTL 2004). To avoid confusion, in this article, we will refer to those "other national languages" as 'regional' languages since each of them (e.g. Fataluku, Bunak, Makasae) is primarily used in a certain region of the country, not nationwide.

During Portuguese colonial rule (until 1975), the language of education was Portuguese. During the Indonesian occupation (1975-1999) the use of Portuguese was forbidden and Indonesian was used as the language of education, although private church-run schools continued to use Tetum (Hajek 2000). Since regaining independence in 2002, Timor-Leste's government has focused on the use of the country's two official languages in its formal education system. Changes were made in 
the schools, in the years following 2002, mainly concerning the proportion of time devoted to Tetum and Portuguese as languages of instruction. Both Shah (2012) and Quinn (2013) examine the consequences of this language-in-education policy. Quinn (2013: 182) shows that in the 2004 Education Policy, the implementation of Portuguese was given precedence over Tetum. Tetum was to be used as 'a pedagogic aide', while in later policies, greater emphasis was given to the use of Tetum. Also Shah (2012) draws attention to differences in the ways in which the two official languages were supported as they were reintroduced into the classroom: a large-scale, compulsory Portuguese language training course was provided for all teachers (see details in the article by Carneiro, in this special issue), but the government did not do the same for Tetum. It appears to have been assumed that the majority of teachers could speak Tetum and so they would be able teach the language, overlooking the fact that it was unfamiliar to most teachers in its newly standardised written form. As a consequence, Tetum has come to be primarily used in its spoken form in schools, as a means of providing explanations to students, while Portuguese is used almost exclusively in classroom texts (see the article by Da Costa Cabral, in this special issue).

Since 2008, the use of regional languages or 'mother tongues' alongside Tetum and Portuguese has been considered for teaching early literacy and curricular content in pre-primary and early primary education. In 2011, the Ministry of Education published new policy guidelines in this area (Ministry of Education 2011a) and launched a pilot project that took place in twelve schools. The project covered three languages in three districts (Galolen in Manatuto, Fataluku in Lautém and Baikenu in Oeccuse). This project was evaluated in 2014 (see Caffery et al. 2014). The wider debate about this language-in-education policy initiative is discussed in detail in Cabral (2013), Taylor-Leech (2013) and Cabral and Martin-Jones (2018).

Although adult literacy rates in Timor-Leste are still low (generally below 60\%; UNDP 2015: 244), the country has had a history of adult literacy policy and practice since at least 1974, when a literacy campaign in Tetum was initiated by FRETILIN (Cabral and Martin-Jones 2008, 2012; Cabral 2019). However, in contemporary policy documents, the target languages and languages of instruction of adult literacy education are hardly mentioned. Timor-Leste's 2002 National Development Plan, for instance, formulates as its goal that "people will be literate, knowledgeable and skilled" (RDTL 2002b: 18). The country's Strategic Development Plan 2011-2030 aims at reducing illiteracy in all age groups of the population (RDTL 2011: 26-39), and the National Education Strategic Plan 2011-2030 strives at eradicating illiteracy in all age groups by 2015 so that "all Timorese are literate" (Ministry of Education 2011b: 115). Although these documents do not specify the language(s) of literacy, it is generally Tetum. Local NGO's, such as the women's organization Grupo Feto Foinsa'e Timor-Lorosa'e (GFFTL) (Young Women's Group, Timor-Leste) (Da Silva 2012), sometimes in collaboration with international organizations, such as Oxfam, have provided adult literacy programs in Tetum, sometimes combined with local languages, in a number of districts. Since 2000, Timor-Leste's Ministry of Education has provided adult literacy programs on a national scale in Tetum, and occasionally in Portuguese, in collaboration with particular development partners, e.g. Brazil (2000-2002). UNDP and UNICEF (2003-2009) and Cuba (2006-2012) 
have also been involved in collaboration with the Ministry of Education as development partners for Tetum-medium programs. These and other international actors have actively been involved in shaping post-independence adult literacy programs in Timor-Leste (see Boughton 2010a, b; Boughton and Durnan 2007; Taylor-Leech 2009; Boon 2011, 2014).

\section{Two studies: methodology and data}

The studies we present here were the first to be conducted in Timor-Leste in different regions where adult literacy classes were being organised. Different kinds of research were carried out over several years and different kinds of data, of a quantitative and qualitative nature, were gathered. Both researchers, Boon and Da Conceição Savio, were familiar with the districts in which they were doing fieldwork. Boon had previously worked with UNDP in the field of adult literacy in Timor-Leste and she speaks a bit of Tetum and understands a lot. Da Conceição Savio is a Timorese university lecturer who is originally from Lautém, the district where he conducted his research. He speaks Fataluku, Tetum and Indonesian.

Boon (2014) carried out research in ten different districts (Aileu, Baucau, Covalima, Dili, Ermera, Liquiça, Manatuto, Manufahi, Oecusse, and Viqueque). Permission for the study was given by the Ministry of Education. During each class visit informed consent was secured at an individual level in face to face interaction with the adult learners in the languages that they preferred. District and sub-district literacy coordinators helped in organizing the study and local literacy coordinators accompanied the researcher and, where necessary, assisted in translating the information given into the regional languages. The study included three types of research: (1) survey work in eight districts; (2) case studies in seven districts, and (3) research on signage in local linguistic landscapes. The research participants included 756 learners and 110 teachers in adult literacy education programs. The literacy learners' mean age was 37.83 (SD 15.33), with their ages ranging from 15 to 78 years; $68 \%$ were women and $32 \%$ men; $69.4 \%$ had never attended formal education. $54 \%$ of the teachers were women and $46 \%$ men; their mean age was 33.8 , with their ages ranging from 19 to 66 years. The survey work with adult learners was based on a questionnaire and involved face to face interviews with all the learners, asking them a few questions and having them complete four literacy tests. The teachers were asked to complete a written questionnaire containing 34 questions. The questionnaires dealt with the participants' language background, their reports of their language abilities, their use of different language resources across domains and their language preferences for literacy education. The case studies were based on 25 semi-structured interviews with nine learner groups, ten teachers and six literacy coordinators. The interview topics included learning needs, ideas on teaching literacy, language use in class, language preference. In addition, 20 adult literacy lessons were observed and audio recorded, field notes were taken and still photography was used to capture particular literacy events. Finally, 322 photographs were taken as a means of mappig the linguistic landscape in the areas surrounding the literacy classes that had been observed. 
Da Conceição Savio (2016) carried out a focused study in the district of Lautém. He devised a questionnaire that was used in interviews with 263 adult participants (or 195 if questions related to reading and writing) in the urban and rural subdistricts of Lospalos and Tutuala respectively. The head of local government gave permission for the data collection and all participants who were selected through random-walk sampling accepted the invitation for an interview and also gave oral informed consent. Participants were free to answer the questions in Tetum, Indonesia or Fataluku. The interviewers (the researcher and a trained assistant) conducted 51 and 212 interviews in the sub-district of Tutuala and Los Palos respectively and completed the questionnaire during the interview. The results showed no statistical difference between the two interviewers ( $\mathrm{T}$ ranging from 0.32 to $1.77, \mathrm{p}$ ranging from 0.75 to 0.08 ). The participants' mean age was 39 years, with their ages ranging from 16 to 83 and with $60 \%$ of participants being older than 40 years. About $60 \%$ were male. The participants' experience of schooling ranged from no education at all (28\%) to 18 years of schooling. About $40 \%$ were working in agriculture, $22 \%$ had private businesses, and there were smaller groups of other participants e.g. office workers, students, teachers, bus conductors and carpenters. The questionnaire for this study was based on 118 questions. This was designed so as to generate participants' self-reports regarding their knowledge of different spoken and written language varieties, regarding their language practices in different formal and informal domains, and regarding their values and attitudes attached to languages, and specifically, regarding Fataluku, Lautém's main regional language. Then, in July and August 2011, 14 adult literacy classes in four different municipalities were observed and audio recorded and field notes were taken. In addition, there was a linguistic landscape component to the study. 298 photographs were taken of different kinds of signage in the sub-districts of Lautém, Tutuala and Lospalos, mainly in the area near the town of Lospalos.

\section{The language resources, values and practices of local social actors: the findings of the two studies in different regions of Timor-Leste}

In this section, we will first present and discuss the findings, focusing in turn on the participants' self-reports of their language resources and abilities, their use of different language and literacy resources and their language attitudes and values. We will then go on to present the findings of the case studies and the observations of adult literacy classes. After that, we will touch briefly on the findings of the research on signage in the linguistic landscape in different districts in Timor-Leste: in Lautém and in other districts.

\section{Language and literacy resources and repertoires: the findings of the questionnaire-based research}

We begin with the study in Lautém and with the 263 respondents who answered the question about the languages they could speak, understand, read and write. $25 \%$ of 
them reported that they only spoke and understood Fataluku. The rest indicated that they spoke and understood two (27\%) or more languages $(40 \%)$. These languages included Fataluku, another regional language (e.g. Makalero or Makasae), Tetum, Indonesian, Portuguese and English.

Out of the 263 respondents, 195 (74\%) reported that they could read and write. $10 \%$ of them reported they could only read Tetum, and about $6 \%$ said that they could only read Indonesian. Others indicated that they could read Fataluku, Tetum and Indonesian (14\%) or Tetum and Indonesian (17\%). Yet others mentioned being able to read other combinations of literacy resources, including English or Portuguese. Similar percentages were reported for writing.

Further analyses showed that education had had a significant effect on the participants' ability to speak and understand languages other than Fataluku. The more educated the respondents were, the more likely they were to indicate that they were able to speak and understand Tetum, Portuguese or Indonesian. Around half of the participants reported facility in writing Tetum and Indonesian. Only a small minority $(15 \%)$ indicated that they read and wrote Portuguese with relative ease.

Boon's (2014) study was carried out in ten other districts of Timor-Leste, with two groups of participants, who were involved in adult literacy education: Adult literacy teachers and adult learners. Her research with teachers revealed a high level of multilingualism but a much lower level of multilingualism among adult literacy learners. All 110 participating teachers reported knowledge of more than one language. In addition to their first language, nearly all of them indicated that they spoke a second and a third language. About $83 \%$ mentioned a fourth language and others even mentioned a fifth language. $80 \%$ had a regional language as their first language and $70 \%$ said that Tetum (including Tetum-Terik, the name given to the variety of Tetum which is spoken as a regional language) was their second language; $55.5 \%$ said they had learned Indonesian as a third language, and $53.6 \%$ said they spoke Portuguese as a fourth language. Of the $26.4 \%$ who said they knew a fifth language, the majority mentioned English.

The language backgrounds of the learners revealed a rather different picture. The majority of the 756 adult learners surveyed (77.8\%) said they knew more than one language; $22.2 \%$ said they only knew one language. These were mainly people from Oecusse and remote areas of Baucau district. Of all learners, $87.7 \%$ indicated that a regional language was their first language, whereas just $12.3 \%$ said that Tetum was their first language. Of the $77.8 \%$ learners who knew more than one language, the majority reported Tetum as their second language. Of the 756 learners, $27.2 \%$ reported a third language, mainly Indonesian. Portuguese was rarely mentioned.

\section{The use of spoken and written language resources: the findings of the questionnaire-based research}

Several questions in the questionnaire used in the research in Lautém dealt with the oral and written use of different languages in a number of private and public domains. Some participants mentioned only one language for a particular domain, but most mentioned more than one language. The results are presented in Table 1 


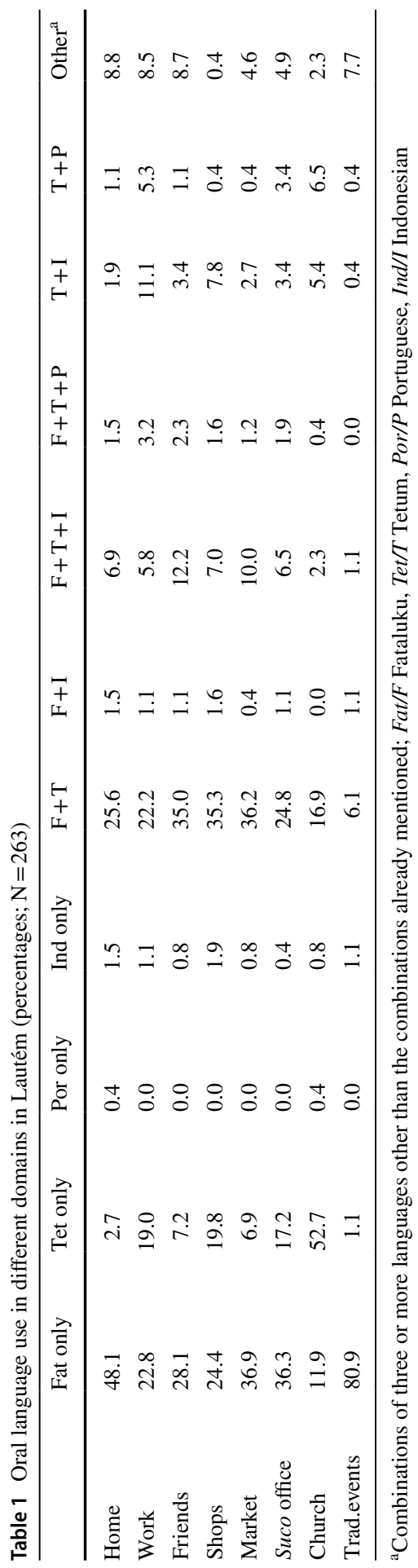


(oral use of languages), Table 2 (languages used in reading) and Table 3 (languages used in writing). The data in the tables are limited to Fataluku, Tetum, Portuguese and Indonesian. However, in addition to these languages and combinations of these languages, the participants also reported other combinations of three or more languages, including local languages and English as being part of their linguistic repertoire.

Table 1 shows that oral Fataluku and Tetum were used in all domains by a majority of the participants. Fataluku was clearly the language of the home and traditional events and Tetum the language of the church. Indonesian was also used by a quarter of the participants at work and with friends. Oral Portuguese was hardly used, except at the workplace or in the suco (municipality) office. Overall, the table clearly depicts the multilingual nature of the oral repertoires of the participants.

Tables 2 shows that with respect to reading, the languages reported most often were Tetum and, for several domains, Indonesian. Hardly any languages were reported as being the only languages used. Sole use of Fataluku and Portuguese was hardly ever mentioned, except for traditional events where Fataluku was used for reading by $40.5 \%$ of the participants. While the sole use of Tetum was high in the domains of home, work, shops and market, it was also dominant in domains such as suco administration (40.9\%) and church (61.2\%). Sole use of Indonesian was reported mainly for shops and the market. In all other domains, combinations of languages were reported as being used in reading. Fataluku was mentioned quite often as a language that was used in reading during traditional events. In most of the domains, Tetum was the language that was most often reported for reading, sometimes in combination with Indonesian. In church the main language used in reading was clearly Tetum. In shops and at the market, a combination of Tetum and Indonesian or only Indonesian were mentioned. Indonesian was also mentioned rather frequently for reading activities at home.

Literacy practices involving online social media were reported along with the responses to questions about reading and writing. The figures show that in texting (SMS) all languages were reported as being used. Here, Tetum and combinations of Tetum with other languages were mentioned most often whereas Portuguese was hardly ever mentioned.

As can be seen from Table 3, for writing the figures were more or less the same: Tetum and Indonesian were often mentioned, in combination with other languages. Fataluku was reported as being used in writing at home, and at traditional events.

Boon's (2014) questionnaire-based research with adult literacy teachers and adult learners in the ten other districts also revealed frequent use of Tetum and regional languages in various domains. We first present her findings for the research carried out with the adult literacy teachers and we then go on to present findings from her research with adult learners.

\section{The adult literacy teachers}

Table 4 shows high percentages of reporting of Tetum use (including Tetum-Terik) by the adult literacy teachers, across all domains in their lives (social and more 


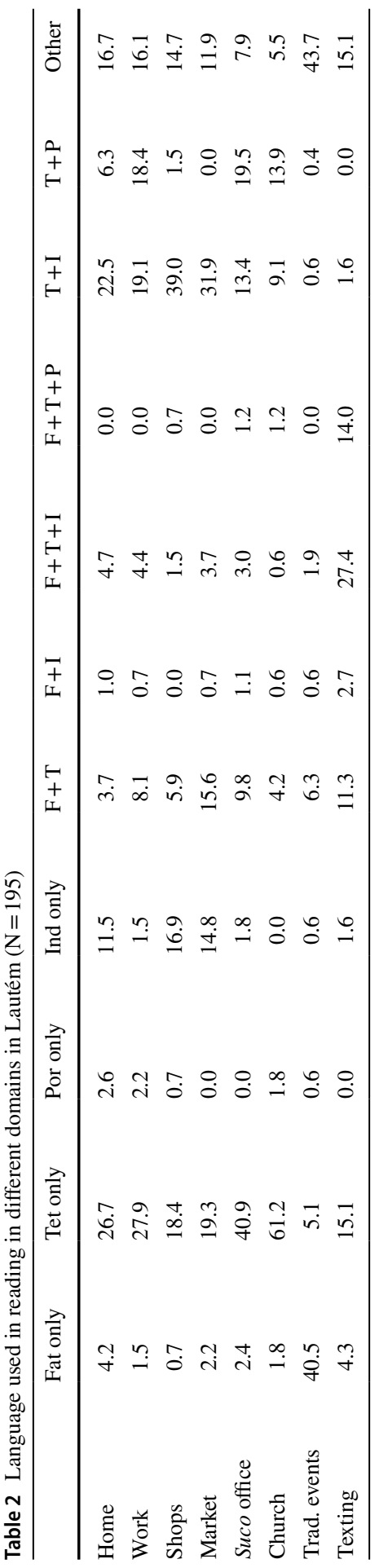




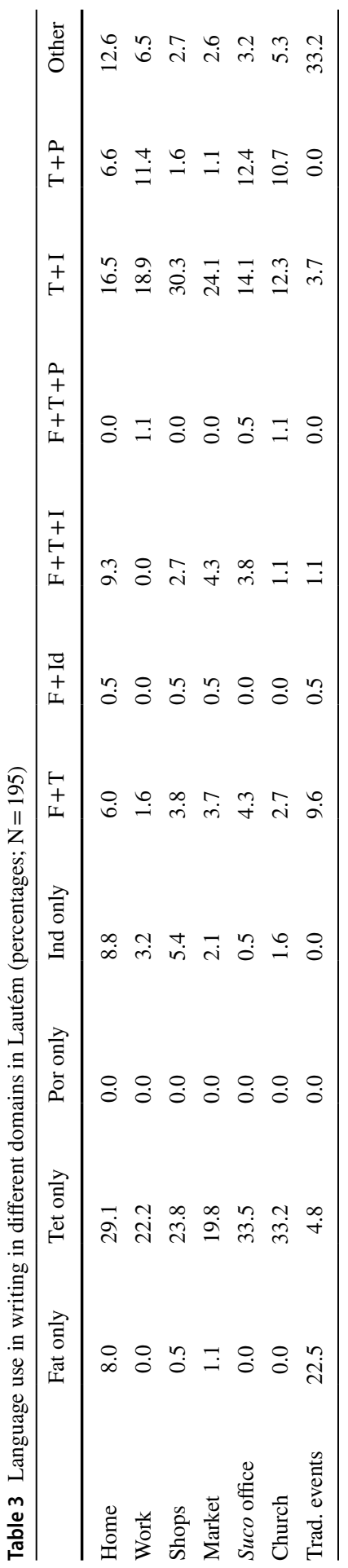


Table 4 Teachers' language use (speaking, reading and writing) in different domains (percentages; $\mathrm{N}=110$ )

\begin{tabular}{lllll}
\hline & $\begin{array}{l}\text { Regional lan- } \\
\text { guage only }\end{array}$ & Tetum only & $\begin{array}{l}\text { Tetum and regional } \\
\text { language }\end{array}$ & $\begin{array}{l}\text { Combination of T } \\
\text { a/o RL a/o P a/o I }\end{array}$ \\
\hline Parents & 49.1 & 21.8 & 28.2 & 0.9 \\
Spouse & 30 & 27.3 & 19.1 & 2.7 \\
Children & 12.7 & 47.3 & 23.6 & 4.5 \\
Family & 14.5 & 33.6 & 49.9 & 1.8 \\
Neighbours & 24.5 & 33.6 & 40.9 & 0.9 \\
Friends & 11.8 & 41.8 & 28.1 & 18.1 \\
Market & 4.5 & 60.9 & 26.3 & 8.1 \\
Administration & 0.9 & 93.6 & 0.9 & 4.5 \\
Church & - & 92.7 & 3.6 & 3.6 \\
\hline
\end{tabular}

a/o and/or, $T$ Tetum, $R L$ regional language, $P$ Portuguese, $I$ Indonesian

institutional ones). It also shows high percentages of reporting of the use of regional languages at home with parents and partners while, with children, regional languages were used less and Tetum was used more. In describing communication with family members and neighbours, a high percentage of participants reported combining Tetum and regional languages. Notable is the absence of Portuguese and Indonesian as the sole language used in any domain (except for $2.7 \%$ who mentioned Portuguese as the only language used in contact with the administration). Apparently, both Portuguese and Indonesian were mostly used in combination with other languages. Some teachers mentioned Portuguese and/or Indonesian as being used in combination with Tetum and/or regional languages when, for example, they were in contact with the administration (combinations including Portuguese) or with friends (mainly combinations including Indonesian, only occasionally including Portuguese).

\section{The adult learners' literacy practices}

Although the learners mentioned a large number of (mainly instrumental) uses of literacy, such as writing their names on forms and reading letters, reading and writing SMS texts and documents, most explained that there were not many occasions in their daily lives in which they would read or write, since their work in the field, at the market, or at home took up most of their time and did not involve any reading or writing. Reading and writing played a key role only in the Tetum literacy classes. Some did do some practice at home, using the literacy primers distributed in the class, due to lack of other reading materials.

\section{Language values and attitudes: the findings of the questionnaire-based research}

Table 5 presents the pattern of responses regarding language values and attitudes generated by the survey work in Lautém. 
Table 5 Language values and attitudes in Lautém (percentages; $\mathrm{N}=263$ )

\begin{tabular}{lcccc}
\hline & Fataluku & Tetum & Portuguese & Indonesian \\
\hline Language liked most & 25.1 & 44.9 & 10.3 & 23.7 \\
Most beautiful & 24.3 & 46.4 & 8.7 & 20.5 \\
Prefer to read (N=195) & 8.7 & 54.4 & 13.4 & 35.6 \\
Prefer to write (N=195) & 5.6 & 58.5 & 14.9 & 39.0 \\
Most useful for future of children & 3.4 & 57.6 & 27.3 & 9.6 \\
Most useful for own future & 40.7 & 42.7 & 9.5 & 9.5 \\
Most useful for future of Timor-Leste & 5.7 & 73.8 & 20.2 & 3.8 \\
Most useful for future of Lautém & 46.0 & 49.0 & 7.2 & 2.7 \\
\hline
\end{tabular}

As Table 5 shows, Tetum was the language that was evaluated most favourably. It was the language that was most liked and it was seen as the most beautiful. It was also the language that most participants preferred to read and write and the language that was considered to be the most useful for the future, for children, for the region and for the nation of Timor-Leste. Fataluku came second in ranking with regard to the first two criteria ('language most liked' and 'most beautiful'). However, it was the language least preferred for reading and writing, for the future of children and for the future of Timor-Leste. In contrast, it was seen as being useful for the future of over $40 \%$ of the participants and for the future of Lautém. This is perhaps due to the way in which the Fataluku language indexes regional identity. Indonesian came close in ranking to Fataluku, with regard to the first two criteria ('language most liked' and 'most beautiful'). It was evaluated favourably by over one third of the participants, as the language they preferred to read and write, but it was not considered to be useful for the future, on any of the criteria. Portuguese had the lowest ranking overall, though just over $20 \%$ of participants saw it as 'useful for the future of Timor-Leste'.

The study by Boon (2014) in ten other districts, with adult literacy teachers and coordinators, and with adult learners, revealed a preference for Tetum as a language of instruction and as a target language in adult literacy education. Regional languages were also seen as having a supporting role with teachers providing extra explanations for participants who were less confident about using Tetum. A few teachers said they would also like to teach literacy with Portuguese as a target language, but then added that the adult learners in their classes did not speak or understand Portuguese.

\section{The findings of the case studies and the observations of adult literacy classes}

In the study by Da Conceição Savio (2016) in Lautém, observations were conducted in 14 adult Tetum literacy classes in four different aldeias (villages): urban Lereloho and Trinta de Agosto, urbanized Caivatxa, and rural Poros. The classes were observed and audio-recorded and field notes were taken. Still photography was also used to capture some literacy events. In addition, literacy coordinators, adult literacy 
teachers and learners were interviewed. Drawing on transcripts of interactions in a total of four classes (380 min teaching time), we give a brief account of the language resources that were used by the teachers and learners in the day to day routines of teaching-learning.

Fataluku was the main language of instruction in these four classes, while the focus of the classes was on the development of literacy in Tetum. Most of the time, the interactions between teachers and students took place in Fataluku, the language that the learners knew best. However, there were some differences across the classes in the four aldeias. In the rural Poros class, Fataluku was the only language of instruction used by the teacher. In Lereloho, Caivatxa and Trinta de Agosto, the teachers also made occasional use of Tetum and Portuguese, in addition to Fataluku, with Tetum being used most often. The teacher in Cavaitxa also made use of Indonesian. In addition, the Fataluku discourse of all four of the teachers showed ample borrowings from other languages such as Portuguese or Indonesian, depending on the educational trajectory of the teacher. The classes were mostly dominated by teacher talk. The learners did not speak a lot. When they did speak, they communicated in Fataluku or read Tetum words aloud from the teaching materials. They also used borrowings from other languages as they spoke in Fataluku and Tetum.

The case studies by Boon $(2011,2013,2014,2019)$ in other districts, and her observations in 20 Tetum adult literacy classrooms, revealed that four languages were often being used in class, i.e., Tetum, a regional language, Indonesian and Portuguese. Tetum was used mostly as the main language of instruction and as the target language for the literacy teaching. Regional languages, such as Makasae in Viqueque and Bunak in Suai, were often used for small talk and had an important function as means of giving instructions and extra explanations when the instruction in Tetum was not fully understood. Indonesian and Portuguese were mostly used to refer to numbers. Sometimes, subject-related terms in Portuguese or Indonesian were introduced by teachers when talking (in Tetum) about literacy and numeracy. Generally speaking, classroom communication was multilingual in nature and participants used all the linguistic resources that were available to them. They sometimes used different languages for specific communicative purposes (to make an aside, or to distinguish the language of the teaching materials from talk about them) but they also moved back and forth from one language to another, with no apparent communicative purpose. Teachers and adult learners, in these adult literacy classes, were getting things done in Tetum, spontaneously using different language resources where needed. In this sense, Boon's findings closely resemble the language practices in adult literacy classes in Lautém described by Da Conceição Savio, albeit with different, more localized use of language resources.

\section{Linguistic landscapes}

Following Blommaert (2013) we consider linguistic landscaping to be a way of providing a first account of the visible sociolinguistic characteristics of an area. Da Conceição Savio (2016) undertook a linguistic landscape analysis of 298 photographs of signs taken in the July-September period in 2012, in 40 aldeias in Lautém. 
The photographs included different types of signs such as graffiti, billboards, notice boards, commercial signs, product information, notes, façade names, still texts, moving texts, posters, banners and border signs. The languages and combinations of languages that appeared on the signs clearly reflected the multilingual character of the area.

Out of a total of 298 signs, about $46 \%$ were monolingual, that is, they were written, printed or carved in just one language, whereas a majority (54\%) had been produced in more than one language. Bilingual signs were the most common but there were also signs with three, four or even five languages. Working across the 298 photographs, we have calculated the number of times resources from each language appeared in this collection of signs from Lautém. The five main languages were: Tetum (44\%), Portuguese (43\%), English, (38\%), Indonesian (36\%) and Fataluku (24\%). Four other languages (Spanish, Italian, French and Chinese) appeared three times and another four languages appeared just once. These were Makasae and Makalero (regional languages) and Korean and Arabic (foreign languages).

It is noteworthy that Fataluku, a regional language, with no standardized orthography as yet, was so visible in the linguistic landscape of Lautém (72 times; $24.16 \%$ ). In almost one quarter of the signs in the corpus, Fataluku played a role. The written form of the language mostly appeared in multilingual signs, interwoven with other languages $(84.72 \%)$. Use of Fataluku in monolingual signs was more limited (15.28\%). When we considered the communicative purpose of these monolingual signs, it turned out that most of them were graffiti- the most grassroots type of communication. Other monolingual signs in Fataluku included billboards, façade names and texts, notice boards, moving texts and notes. Where Fataluku appeared on billboards, façade texts and notice boards, it referred almost exclusively to names of sucos, aldeias, firms and institutions that had a Fataluku origin. Some traditional house and family names also appeared in Fataluku on clan house façades (See Figure 1 for an example).

One further observation we made regarding the monolingual signs in Fataluku was that there was considerable variation in orthographic conventions. Take, for example, the writing of the Fataluku word for house as le'e, lee and le respectively in different signs. This reflects the fact that work is still underway on the standardization of the orthography of Fataluku. The variation in writing practices indexes the grassroots character of writing in Fataluku in Lautém. Similar observations have been made by Blommaert (2008), in his research in Africa.

Boon's linguistic landscape research, in other districts, revealed that the sites surrounding the adult literacy classes were rather low-literate environments, with relatively little signage. However, the churches and the markets did have a large variety of signs, and writing in different languages was displayed. The linguistic landscape in the streets adjacent to the markets and the churches could also be characterized as multilingual. Nine languages were identified in a total of 322 signs in public spaces: Tetum, Portuguese, Indonesian, English, Makasae, Latin, Chinese, Arabic and Spanish. In $60 \%$ of the signs, more than one language was used. They included bilingual signs $(36 \%)$, or trilingual $(20 \%)$ and quadrilingual ones $(4 \%)$. Tetum occurred in $42 \%$ of the signs as the main language or one of the main languages (thus facilitating understanding of messages in these signs), Portuguese and English were used 


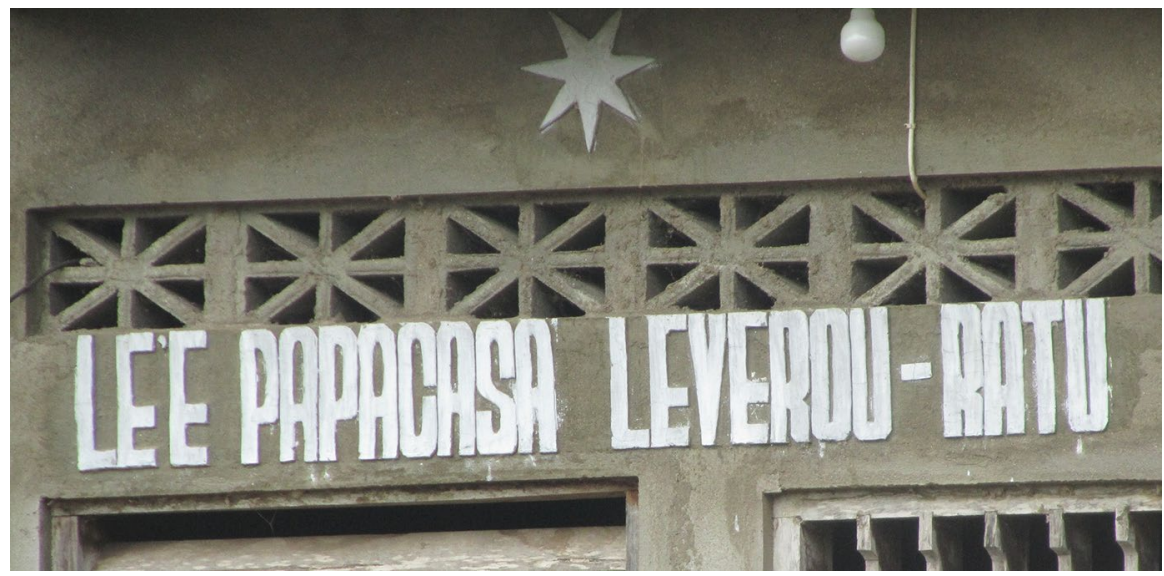

Figure 1 Traditional house name in Fataluku in Poros, Lautém (copyright Edegar da Conceição Savio)

in the construction of $31 \%$ of the signs, and Indonesian in $22 \%$. The combination of language resources varied across different types of signs. Most billboards, banners, paper copies, posters, and commercial signs showed Tetum as their main language. Tetum was also the language that was most visible in public notices, such as those providing information on government policies regarding health, elections, population counts. In addition, Tetum predominated in signs pertaining to local information on ceremonies, courses or products on sale.

The way that Tetum was combined with other languages indexed the source of the sign. For example, an official billboard of the Ministry of Finance on taxes showed the name of the Ministry and its Tax Department in Portuguese and then explained in Tetum what it was all about: Receitas hosi imposto desenvolve nasaun sai forte. Mai ita hamutuk desenvolve Timor-Leste. Mai hola parte iha desenvolvimento nasaun, selu ita nia imposto (Income from tax is to develop a strong nation. Come let us together develop Timor-Leste. Come and be part of the nation, by paying your taxes). On this billboard, text in Tetum predominated. However, most notice boards linked to governmental institutions in public buildings used Portuguese as the main language.

In contrast, most product packaging contained information in either Indonesian or English, since many products are imported from Indonesia and Australia. In general, the more local messages were (in terms of production and target audience), the more Tetum was used as the main language. This included banners, commercial signs, posters, and paper copies. Nevertheless, multilingualism predominated in signs, particularly in areas near shops, markets and churches: four different languages were regularly used in these public spaces and many signs contained multiple languages, with Tetum having a salient role. See for example the commercial sign in Figure 2.

The sign uses four languages: The first line iha ne'e loke (here open(s)) is Tetum (in larger characters), Rental is English and computador (computer) is Portuguese, foto copi is a mix of Indonesian and English orthography (foto kopi), jilid (binding) is Indonesian and $D L L$ finally is an acronym for Indonesian dan lain-lain (etcetera). 


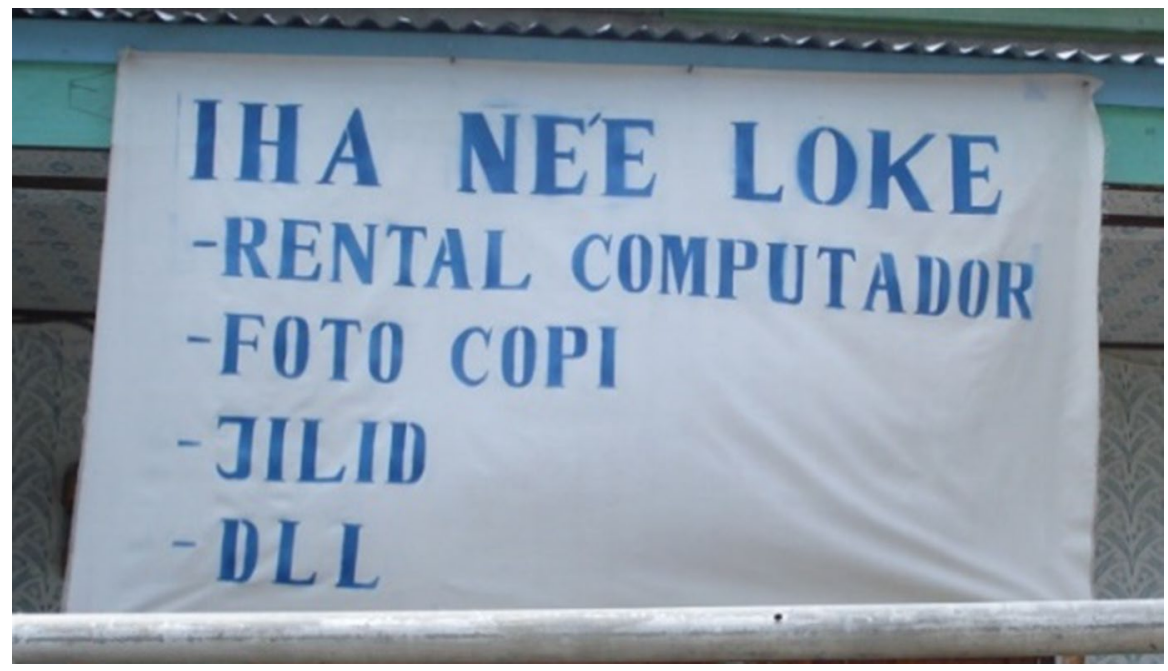

Figure 2 Commercial sign using four languages in Suai, Covalima (copyright Danielle Boon)

\section{Summary and concluding comments}

We begin this final section with a brief summary of the main findings of the empirical work presented above. We then discuss the implications of the findings for language-in-education policy making.

\section{Summary}

Firstly, most of the participants in the two studies we drew upon in this article reported that they had knowledge of more than one language. Tetum was the language that was known best by most participants, in its spoken form as well as its written form. Most participants also reported knowledge of the language spoken in their region of the country. Some also indicated that Indonesian and/or Portuguese were part of their communicative repertoire, depending on their age and educational experience. The spread and knowledge of Indonesian can be explained by the fact that Indonesian was the only language of schooling, and the only official language, during the Indonesian occupation (1975-1999). We expect Portuguese to grow as a language of literacy in the years to come, along with Tetum, as a consequence of their increasing use in education. Only a limited number of participants mentioned English.

Secondly, many participants indicated that they drew on their regional language resources in the most private domains of their lives. In the public sphere, Tetum was widely used. Indonesian was also commonly used, particularly in commercial transactions. Portuguese was used in administrative settings, along with Tetum.

Thirdly, the survey data related to language attitudes showed that Tetum was considered to be the most valued language in Timor-Leste. Most participants in the study in Lautém evaluated it favourably for all communicative purposes. They also 
saw Tetum as being the 'most useful language' for the future of the children and for the future of the country. However, Fataluku, the regional language was deemed to be the 'most useful language' for the future of the region. In contrast, Portuguese had rather low ratings. In the other districts, Boon (2014) found that Tetum was assigned the highest value for adult literacy education. As in Da Conceição Savio's study, participants indicated that they saw Tetum as having the highest value for all communicative purposes, while the regional languages served as local emblems of identity.

Fourthly, the observations carried out by both researchers in adult literacy classes revealed that Tetum was the main language of instruction, with the exception of Lautém, where the regional language (Fataluku) was widely used while teaching and learning literacy in Tetum. While these two languages predominated in the classroom discourse, teachers and students drew on a range of other language resources in the daily rounds of interactional life in the literacy classes. These other resources were drawn from Indonesian (especially when counting or doing numeracy work) and from Portuguese (in, for example, the use of some metalanguage). Teachers also moved back and forth between Tetum and regional languages to make asides, do small talk or to give extra explanations on the task in hand.

Finally, Timor-Leste's linguistic landscape clearly indexes the multilingual character of the country. The majority of the public signs, that were analysed in the two studies, included resources from more than one language. Depending on their date of construction, and the purpose of the sign-maker, the signs incorporated different combinations of linguistic resources. Thus, Tetum and Portuguese were mainly found in official signs produced by governmental bodies. Indonesian appeared in old border signs and on commercial signs. Regional languages were not represented very often though Fataluku was used in graffiti in Lautém and in the names on the façades of traditional houses.

\section{Concluding comments}

The findings of these two studies in Timor-Leste remind us that language policy processes are always situated and, as we have seen here, they unfold in very different sociolinguistic settings, where different groups of adults have very different language repertoires, resources and language values. Studies of the sociolinguistic realities 'on the ground', in different regions, need to be conducted as new languagein-education policies are introduced.

The design and conduct of these studies will vary, though the research reported here suggests that considerable advantages accrue from employing mixed research methods. The questionnaire-based research, with a significant sample of participants, enabled us to build a broad picture of the nature and extent of linguistic diversity in each of the regions. The linguistic landscape research enabled us to capture the multilingual nature of local practices, in different types of signs-signs that could be used in developing ecologically valid reading materials for adult literacy teaching. And, the observations of adult literacy classes provided insights into the actual language practices of teachers and adult learners and into the local processes 
of policy instantiation. Moreover, the interviews with teachers and learners provided insights into their own emic perspectives on these processes. From this part of the research conducted in the two studies, there are clear signs that teachers and learners in adult literacy education in Timor-Leste were making their own contributions to the shaping of policy processes 'on the ground', identifying pragmatic local solutions to the communicative challenges they faced in their classes.

From the two studies presented here, we also see that Tetum was favourably evaluated as a resource for wider communication by most of the participants in the study and, at the same time, we see that it was often drawn upon as a communicative resource, in speaking and in writing, and in constructing written signs, in conjunction with other resources, such as regional languages and/or Indonesian and, less frequently, Portuguese. So, the actual language-in-education policy commitment to the adoption of Tetum as a medium of instruction and as the language of literacy in adult literacy classes resonates quite well with the sociolinguistic realities 'on the ground', and with the language values being expressed by participants in the different regions included in the two studies. However, key social actors involved in the development and refinement of policy-processes, at different levels of the adult education system, need to acknowledge the agentive ways in which local teachers and adult learners navigate the policy focus on Tetum. They do so by drawing on different communicative resources, such as regional languages like Fataluku, in addition to Tetum, in the day to day interactional routines of the adult literacy classes. Although using Tetum as a medium of instruction seems to be a sound policy, our findings show that policy making processes need to acknowledge the ways in which also other linguistic resources are drawn on in adult literacy classrooms. If we consider adult literacy teaching a way to give the learners a voice of their own, all languages that are part of their linguistic repertoires should be considered as possible (additional) languages of instruction and languages of literacy.

More detailed case study research is still needed into the discursive and interactional practices of teachers and adult learners in literacy classes such as those depicted here-and into the local processes of policy instantiation. Research of this kind would involve audio-recording and analysis of multilingual classroom talk and uses of texts in Tetum. It would provide further insights into the subtle, creative and situated ways in which meanings are exchanged between teachers and adult learners. It would also provide insights into the nature of the pedagogic practices emerging in such contexts, across different kinds of literacy programmes.

In order to refine and develop language-in-education policy for adult literacy education over time, the case needs to be made for greater involvement of teachers and learners in this part of the research process. As Dell Hymes (1980: 115) once observed, when he was asked to evaluate a bilingual programme, teachers are not mere "bystanders", they have "the finest possible grasp of the program". Close collaboration between teachers and researchers can create valuable space for dialogue, reflection and joint knowledge-building about policy processes. As Van der Aa and Blommaert (2017: 209) have pointed out, this kind of close dialogue, reflection and joint knowledge-building between researchers and practitioners, teachers as well as learners, serves as a means of creating "epistemic solidarity". By initiating such research collaboration, researchers have the opportunity to bring new voices into the 
study of policy-making processes (Juffermans and Van der Aa 2013) and to contribute in this way to the forging of new directions.

\section{Funding}

Open Access This article is licensed under a Creative Commons Attribution 4.0 International License, which permits use, sharing, adaptation, distribution and reproduction in any medium or format, as long as you give appropriate credit to the original author(s) and the source, provide a link to the Creative Commons licence, and indicate if changes were made. The images or other third party material in this article are included in the article's Creative Commons licence, unless indicated otherwise in a credit line to the material. If material is not included in the article's Creative Commons licence and your intended use is not permitted by statutory regulation or exceeds the permitted use, you will need to obtain permission directly from the copyright holder. To view a copy of this licence, visit http://creativecommons.org/licen ses/by/4.0/.

\section{References}

Arthur, J. (1996). Code switching and collusion: Classroom interaction in Botswana primary schools. Linguistics and Education, 8(1), 17-33.

Blommaert, J. (2008). Grassroots literacy: Writing, identity and voice in Central Africa. London: Routledge.

Blommaert, J. (2013). Ethnography, superdiversity and linguistic landscapes. Chronicles of complexity. Bristol: Multilingual Matters.

Blommaert J., \& Kroon, S. (2015). From language to register in language policy research. In Keynote at the multidisciplinary approaches in language policy and planning conference, Calgary, 3-5 September 2015.

Boon, D. (2011). Adult literacy teaching and learning in multilingual Timor-Leste. Compare: A Journal of Comparative and International Education, 41(2), 261-276.

Boon, D. (2013). Multilingual classroom talk in adult literacy education in Timor-Leste: Teachers and learners doing literacy and numeracy tasks. Language and Education, 27(4), 356-373.

Boon, D. (2014). Adult literacy education in a multilingual context: Teaching, learning and using written language in Timor-Leste. Ph.D. thesis, Tilburg University.

Boon, D. (2019). Adult literacy in Timor-Leste: Insights from ethnographic work with teachers, learners and coordinators of contemporary literacy programs. International Journal of the Sociology of Language, 259, 63-83.

Boughton, B. (2010a). Ten years on: Adult education and development in Timor-Leste. In M. Leach, N.C. Mendes, A.B. da Silva, A. da Costa Ximenes \& B. Boughton (Eds.),Understanding Timor-Leste (pp. 255-260). Hawthorn: Timor-Leste Studies Association.

Boughton, B. (2010b). Back to the future? Timor-Leste, Cuba and the return of the mass literacy campaign. Literacy and Numeracy Studies, 18(2), 58-74.

Boughton, B., \& Durnan, D. (2007). The political economy of adult education and development. In D. Kingsbury \& M. Leach (Eds.), East Timor: Beyond independence (pp. 209-221). Melbourne: Monash Asia Institute.

Cabral, E. (2013). The development of language policy in a global age: The case of East-Timor. In J. Arthur Shoba \& F. Chimbutane (Eds.), Bilingual education and language policy in the global south (pp. 83-103). New York: Routledge.

Cabral, E. (2019). Timor-Leste 1974-1979: Decolonisation, a nation-in-waiting and an adult literacy campaign. International Journal of the Sociology of Language, 259, 39-61.

Cabral, E., \& Martin-Jones, M. (2008). Writing the resistance: Literacy in East-Timor 1975-1999. International Journal of Bilingual Education and Bilingualism, 11(2), 149-169.

Cabral, E., \& Martin-Jones, M. (2012). Discourses about adult literacy and about liberation interwoven: Recollections of the adult literacy campaign initiated in 1974/5. In M. Leach, N. Canas Medes, A.B. 
da Silva, B. Boughton \& A. da Costa Ximenes (Eds.), New research on Timor-Leste (pp. 342-348). Swinburne: Timor-Leste Studies Association.

Cabral, E., \& Martin-Jones, M. (2018). Paths to multilingualism? Reflections on developments in language-in-education policy and practice in East-Timor. In L. Lim, C. Stroud, \& L. Wee (Eds.), The multilingual citizen: Towards a politics for agency and change (pp. 120-149). Bristol: Multilingual Matters.

Caffery, J., Coronado, G., Hodge, B., \& Taylor-Leech, K. (2014). The Timor-Leste mother tongue-based multilingual education pilot project: A strategic evaluation. Retrieved (in 2016) from www.canbe rra.edu.au/researchrepository.

Canagarajah, S. (1993). Critical ethnography of a Sri Lankan classroom: Ambiguities in student opposition to reproduction through ESOL. TESOL Quarterly, 27(4), 601-626.

Cooper, R. L. (1989). Language planning and social change. Cambridge: Cambridge University Press.

Da Silva, A.B. (2012). FRETILIN popular education 1973-1978 and its relevance to Timor-Leste today. Ph.D. thesis, University of New England.

De Araújo e Corte-Real, B., \& Kroon, S. (2012). Becoming a nation of readers in Timor-Leste. In M. Leach. N. Canas Mendes, A.B. da Silva, B. Boughton \& A. da Costa Ximenes (Eds.), New research on Timor-Leste (pp. 336-341). Swinburne: Timor-Leste Studies Association.

Da Conceição Savio, E. (2016). Studi sosiolinguistik bahasa Fataluku di Lautém(A sociolinguistic study of the Fataluku language of Lautém). Ph.D. thesis, Leiden University.

Hajek, J. (2000). Language planning and the sociolinguistic environment in East Timor: Colonial practice and changing language ecologies. Current Issues in Language Planning, 1(3), 400-414.

Heller, M. (1999). Linguistic minorities and modernity. London: Longman.

Heller, M. (2018). Socioeconomic junctures: Theoretical shifts: A genealogy of language planning and policy research. In J. W. Tollefson \& M. Pérez-Milans (Eds.), Oxford handbook of language policy and planning (pp. 35-50). Oxford: Oxford University Press.

Hornberger, N. H. (2006). Frameworks and models in language policy and planning. In T. Ricento (Ed.), An introduction to language policy: Theory and method (pp. 24-41). Malden, MA: Blackwell Publishing.

Hornberger, N. H., \& Johnson, D. C. (2007). Slicing the onion ethnographically: Layers and spaces in multilingual language education. TESOL Quarterly, 41(3), 509-532.

Hult, F. (2010). Analysis of language policy discourses across the scales of space and time. International Journal of the Sociology of Language, 202, 7-24.

Hymes, D. (1980). Language in education: Ethnolinguistic essays. Washington, DC: Center for Applied Linguistics.

Johnson, D. C. (2009). Ethnography of language policy. Language Policy, 8, 139-159.

Johnson, D. C. (2013). Language policy. New York: Palgrave McMillan.

Johnson, E. J. (2012). Arbitrating repression: Language policy and education in Arizona. Language and Education, 26(1), 53-76.

Juffermans, K., \& Van der Aa, J. (2013). Introduction to the special issue: Analyzing voice in educational discourses. Anthropology and Education Quarterly, 44(2), 112-123.

Kaplan, R. B., \& Baldauf, R. B. (1997). Language planning: From practice to theory. Clevedon: Multilingual Matters.

Lin, A. M. Y. (1996). Bilingualism or linguistic segregation? Symbolic domination, resistance and codeswitching. Linguistics and Education, 8(1), 49-84.

Makoni, S., \& Pennycook, A. (Eds.). (2007). Disinventing and reconstituting languages. Clevedon: Multilingual Matters.

Makoni, S., \& Mashiri, P. (2007). Critical historiography: Does language planning in Africa need a construct of language as part of its theoretical apparatus? In S. Makoni \& A. Pennycook (Eds.), (2007) Disinventing and reconstituting languages (pp. 62-89). Clevedon: Multilingual Matters.

Marten, H. F. (2016). Sprach(en)politik. Eine Einführung. Tübingen: Narr Francke Attempto Verlag.

Martin-Jones, M., \& Da Costa Cabral, I. (2018). The critical ethnographic turn in research on language policy and planning. In J. W. Tollefson \& M. Pérez-Milans (Eds.), Oxford handbook of language policy and planning (pp. 71-92). Oxford: Oxford University Press.

McCarty, T. (Ed.). (2011). Ethnography and language Policy. London: Routledge.

Ministry of Education. (2011a). Mother tongue-based multilingual education for Timor-Leste: National policy. Dili: Komisaun Nasional Edukasaun.

Ministry of Education. (2011b). National education strategic plan 2011-2030, August 2011. Dili: Ministry of Education. Retrieved https://www.globalpartnership.org. 
Quinn, M. (2013). Talking to learn in Timorese classrooms. Language, Culture and Curriculum, 26(2), $179-196$.

RDTL. (2002a). Constitution of the democratic republic of Timor-Leste. Dili: República Democrática de Timor-Leste.

RDTL. (2002b). National development plan. Dili: República Democrática de Timor-Leste.

RDTL. (2004). Orthographical standard of the Tetum language. Dili: República Democrática de Timor-Leste.

RDTL. (2011). Timor-leste strategic development plan 2011-2030. Dili: República Democrática de Timor-Leste.

Ricento, T., \& Hornberger, N. (1996). Unpeeling the onion: Language planning and policy and the ELT professional. TESOL Quarterly, 30(3), 401-427.

Shah, R. (2012). Goodbye conflict, hello development? Curriculum reform in Timor-Leste. International Journal of Educational Development, 32, 31-38.

Silverstein, M. (2003). Indexical order and the dialectics of sociolinguistics. Language and Communication, 23, 193-229.

Taylor-Leech, K. (2009). The language situation in Timor-Leste. Current Issues in Language Planning, $10(1), 1-68$.

Taylor-Leech, K. (2013). Finding space for non-dominant languages in education: Language policy and medium of instruction in Timor-Leste 2000-2012. Current Issues in Language Planning, 14(1), $109-126$.

UNDP. (2015). Human development report 2015. Work for human development. New York: United Nations Development Program.

Van der Aa, J., \& Blommaert, J. (2017). Ethnographic monitoring and the study of complexity. In M. Martin-Jones \& D. Martin (Eds.), Researching multilingualism: Critical and ethnographic perspectives (pp. 259-271). Abingdon, OX: Routledge.

Publisher's Note Springer Nature remains neutral with regard to jurisdictional claims in published maps and institutional affiliations.

Danielle Boon is a teacher, teacher trainer and researcher in adult literacy and second language education. She currently teaches Dutch and academic skills at the Tilburg University Language Center. She worked in Timor-Leste as a UNDP adult literacy advisor for the Ministry of Education (2003-2008) and she was a Ph.D. researcher in the project Becoming a Nation of Readers in Timor-Leste at Tilburg University (2009-2014) where she obtained her Ph.D. She speaks Dutch, English, Portuguese, German, French and some Tetum.

Edegar da Conceição Savio born in Lospalos, Lautém, Portuguese Timor, was a Ph.D. researcher at Tilburg University and Leiden University in the project Becoming a nation of readers in Timor-Leste (20092014). He obtained his Ph.D. in Leiden in 2016. He lives in the Netherlands and occasionally lectures at the University of Dili and the University da Paz in Timor-Leste. Between 2018 and 2019 he participated in a project on the border dispute settlement between Indonesia and Timor-Leste. He is proficient in Fataluku, Indonesian and Tetum.

Sjaak Kroon is Professor of Multilingualism in the Multicultural Society at the Department of Cultures Studies and a member of Babylon at Tilburg University. His main focus in research and teaching is on linguistic and cultural diversity, language policy, literacy and education in the context of globalization. He led the research team working on the project entitled Becoming a nation of readers in Timor-Leste (2009-2014). Recent publications, with Jos Swanenberg, include Language and Culture on the Margins (Routledge 2019) and Chronotopic Identity Work (Multilingual Matters 2020). He speaks Dutch, English, German and some French.

Jeanne Kurvers was formerly an Associate Professor at Tilburg University, now retired. Her main focus in research is on literacy and second language acquisition of children and adults. She was a member of the research team working on the project entitled Becoming a Nation of Readers in Timor-Leste (20092014). Dr. Kurvers is currently involved in work on adult literacy education and integration policy and in 
the development of a European Reference Guide on literacy acquisition and second language learning for adult migrants (CoE). She speaks Dutch, English, French and German. 